U.S. DEPARTMENT OF THE INTERIOR

U.S. GEOLOGICAL SURVEY

\title{
DEEP GEOELECTRIC STRUCTURE FOR MINERAL RESOURCE ASSESSMENT IN THE PAYETTE NATIONAL FOREST, IDAHO
}

\author{
by \\ Brian D. Rodriguez, William D. Stanley, and William D. Heran \\ Open-File Report $96-666$
}

This report is preliminary and has not been edited or reviewed for conformity with the U.S. Geological Survey editorial standards. Any use of trade names is for descriptive purposes only and does not imply endorsement by the U.S. Geological Survey.

Denver, Colorado 


\section{INTRODUCTION}

A recently completed mineral resource assessment in Roadless Areas of western Idaho involved a multidisciplinary geochemical, geological and geophysical study. Electrical geophysical methods were employed to evaluate the potential for major ore bodies in the contact areas between the Idaho batholith and older sedimentary and metamorphic rocks. In 1989, data were collected to regionally characterize the Earth's crust in the four Roadless Areas of western Idaho shown in Figure 1. This study was designed to provide the diagnostic parameters necessary to determine the nature of intrusive rocks, the type of rocks in contact with them, the location of major structural features that might channel mineralizing fluids, and the specific alteration zones that might directly be related to mineral deposits.

The search for individual mineral deposits requires selection of an mineral deposit model. An understanding of the regional geologic background is also required for a properly focused mineral assessment. For this study, a better understanding of the cretaceous plutonic rocks, Tertiary volcanic and plutonic rocks, and accreted island arc rocks was necessary. Many of the significant mineral deposits of Idaho are the result of a complex interaction between heat producing intrusive bodies and nearby metal-rich sedimentary and metamorphic rocks. A suitable transect in western Idaho to study this relationship was selected from New Meadows to Stibnite, a roughly east-west profile (A-A', Figure 1). This was an important transect for assessment of Roadless Areas, because four of the larger Roadless Areas (French Creek, Secesh-Lick Creek East, Payette Creek, and South Fork) straddled the profile.

\section{MAGNETOTELLURIC METHOD}

Magnetotellurics, an electrical geophysical method was used to study physical properties associated with lithologic units and fracture systems of the crust along this transect. This technique measures the electrical resistivity of the rocks, and in many instances, can be used to determine whether the rocks are intrusive, volcanic, sedimentary, or metamorphic. Fracturing and alteration zones can also be mapped.

The magnetotelluric method (Kaufman and Keller, 1981; Vozoff, 1991) is an electromagnetic frequency-sounding technique utilizing natural variations of the Earth's magnetic and electric field originating in geomagnetic micropulsations over the frequency range from 0.0001 to $1 \mathrm{~Hz}$ and energy from world-wide lightning activity at frequencies of 1 to $10,000 \mathrm{~Hz}$. The natural electric and magnetic fields are recorded in two orthogonal, 
horizontal directions (the vertical magnetic field is sometimes recorded as well). Measurements are recorded at the Earth's surface with a computer-based data-acquisition and processing system. The resulting time-series signals are transformed into the frequency domain and used in a cross-spectral analysis to derive earth tensor resistivities and phases. Generally, a rotated coordinate system that corresponds to resistivity measured along electrical strike (called the transverse electric, $\mathrm{TE}$ direction) and normal to strike (called the transverse magnetic, TM direction) is used. In two-dimensional and threedimensional modeling, models are derived to fit both the TE and TM resistivities.

Measurement of earth resistivities can be an effective means of mapping geologic structures because of the large variation in the electrical resistivity of rocks. The resistivity of geologic units is largely dependent upon their temperature, fluid content, alteration, fracturing, carbon, and other conductive mineral content (Keller and Frischknecht, 1966). Fluids within the pore spaces can reduce resistivities in a high-resistivity rock matrix, especially when fluid salinity and rock porosity are high. Also, resistivities can be lowered by the presence of highly conductive clay minerals, graphitic carbon, and metallic mineralization. It is also common in volcanic rocks and in fault zones to have conductive authigenic minerals and gouge that have resistivities one or two orders of magnitude lower than those of the surrounding rocks (Nelson and Anderson, 1992). Increased temperatures cause higher ionic mobility and mineral activation energy, reducing rock resistivities significantly.

The magnetotelluric method has distinct advantages over other geophysical techniques in the geologic study of complicated geological environments because of the wide range of rock resistivities and the inherent tensor nature of the method, which makes it sensitive to vertical structures. Furthermore, the method is capable of establishing whether the subsurface structures being measured are effectively one-, two-, or threedimensional in terms of their response to the electromagnetic fields.

Time-varying magnetic fields that originate from naturally occurring sources induce time-varying current flow in the conductive earth. The Earth's resistivity is determined from the relationship of these time-varying magnetic and electric fields (electrical impedance). Because lower frequencies penetrate deeper, the measurement of a spectrum of frequencies allows the creation of an electrical sounding, which is a measure of the electrical resistivity versus frequency. In a plane layered earth the magnetotelluric sounding could be simply inverted to produce a plot that shows resistivity with depth. However, the Earth is 
seldom plane layered, and the magnetotelluric method responds to lateral variations of resistivity. For a two-dimensional earth, i.e. an earth that varies only with depth and in the direction perpendicular to the strike, profiles of magnetotelluric soundings may be inverted to produce electrical resistivity cross-sections. Although some of the geologic structure has limited strike length and is very complex, the linear nature of most of the structures in this region makes two-dimensional modeling useful for approximating the local geology.

\section{SURVEY COVERAGE AND DATA PARAMETERS}

Twenty magnetotelluric soundings were located along profile $A-A^{\prime}$ (Figure 1) with spacing that varied from 2 to 10 kilometers. Frequencies sampled ranged from 0.001 to $300 \mathrm{~Hz}$ using single station recordings of both orthogonal horizontal components of the electric and magnetic fields. These data were measured with U.S. Geological Survey-designed instrumentation and processed in real-time with the computer that controls the magnetotelluric system. The recorded time-series data were transformed to the frequency domain and Fourier analyzed to determine a twodimensional resistivity and phase tensor at each site. The data were then freely-rotated to maximum and minimum resistivity directions so that propagation modes for the signals were decoupled into transverse electric (TE) and transverse magnetic (TM) modes. The TE and TM modes are equivalent to measurement of the earth's resistivity with the electric field directed along and across the geologic strike, respectively. This data analysis method uses the crosspower method of Gamble et al. (1979), which produces estimates of apparent resistivity that are subject to large random errors when coherencies are less than 0.9. Therefore, the observed data were manually smoothed and digitized in an effort to reduce systematic errors, random errors, and coherent noise. Plots of tensor resistivity for the manually smoothed representations of the magnetotelluric data are shown in Figure 2, along with the modeled data curves.

If the data are obtained over structures that are threedimensional, the skew of the tensor will have significant values, whereas for a truly two-dimensional earth the skew will be zero. Most of the data from the survey had low skew values, typically 0.1 to 0.3 , but near stations $7,8,9$, and 10 , skew values for some frequency ranges were from 0.3 to 1 . A northeast principalaxis rotation of the resistivity tensors was associated with the western half of the profile. A northwest rotation azimuth of the tensor principal direction was associated with the eastern half of the profile. The high skew values at station 7 suggest a three-dimensional electrical structure, which means the underlying resistivity structure may be limited in strike length. 
Stations 8, 9, and 10, however, suffered from poor data quality, so it is likely the high skews exhibited were the result of poor data.

\section{TWO-DIMENSIONAL MODEL}

\section{Description and Considerations}

The MT data were modeled with a 2-D inversion algorithm (Smith and Booker, 1991) called the rapid relaxation inverse (RRI) because of similarities to classical relaxation solutions and because of its great operational speed. This method, which is one to two orders of magnitude faster than more conventional methods of 2-D inversion, utilizes approximate partial derivatives of $\mathrm{MT}$ data with respect to the conductivity directly beneath the measurement site and ignores cross-terms of horizontal field-gradients and conductivity gradients. Effectively, the iterations process involves intermediate $1-D$ inversions that are used to construct a 2-D model needed to obtain new sets of model residuals from 2-D forward calculations for subsequent iterations. The algorithm has been tested with numerous synthetic-model data sets and has proven to converge to the correct geometry of these models. In our experience with data from this survey and several others, we have found that the RRI method provides a rapid means of 2-D modeling that achieves excellent fits to the observed data. The other advantage to the RRI inversion method stems from the use of a minimum-structure criteria (Smith and Booker, 1988), in which the algorithm applies a selected number of final iterations steps in which the complexity of the model is reduced while maintaining an overall good fit to the data. These latter steps substantially reduce model artifacts in the final solution. In addition, the effects of near-surface resistivity anomalies that cause "static shifts" (Sternberg, et al., 1988) of the data can be reduced by utilizing a distortion matrix in the program. This shift was manually corrected in the more severely soundings by using comparisons with unshifted data nearby. For the remainder of the data, we used the technique of Booker (1991), which involves determining the distortion coefficients using a joint TE-TM inversion first, followed by a TE inversion only. No resolution statistics are provided on the uniqueness of the derived models, but, with the use of minimum-structure constraints, one can be assured that the totality of models that fit the data is reduced to a small set of simplest models. The program can be run with different starting models and error assumptions to more thoroughly investigate the range of possible models.

An interpretative cross-section is shown in Figure 3. The grid used in this model consisted of 72 × 34 variable dimension 
cells extending to several hundred kilometers horizontally and one hundred kilometers vertically to minimize edge effects. The precise distribution of the resistivity units are not wellconstrained, and could conceivably be different from Figure 3 and still be consistent with the observed data. The resolution of the resistivity boundaries is in part, a function of the model grid mesh design. The two-dimensional model computed fits to the observed data were generally within measurement errors in the data. Attempts were made to keep the model simple. The final model is simple and provides the best-fitting discrete twodimensional model that could be derived.

Resistivity in rocks can be reduced by fracturing, conductive pore fluids, and alteration minerals. Unaltered, unfractured crystalline rocks are normally very resistive. Marine sedimentary rocks and clay-rich alluvium are normally very conductive. Metamorphic rocks, including gneiss, schists (nongraphitic), and marble are moderately to highly resistive. There is, of course, overlap in resistivities between all of these rock types. The reader is, therefore, cautioned to remember that the resistivity model boundaries are somewhat insensitive to precise lithologic boundaries.

$\underline{\text { Results }}$

The two-dimensional model illustrates some important aspects of geology along the transect that are significant to a detailed mineral assessment of the four Roadless Areas. The deep resistivity structure (Figure $3 a$ ) of the western half of the profile is consistent with current ideas of a collage of accreted volcanic arc terranes (Hamilton, 1978; Brooks, 1979) that are welded to the pre-late Cretaceous continental margin that is defined approximately by the Sr87/Sr86,.704-.706 isopleth (Armstrong, et al., 1977). Working our way down from the surface, of our interpreted cross-section (Figure 3b), beginning with the western half of the profile, we find the near-surface $10 \mathrm{ohm}-$ meter unit measured primarily under stations 6, 7 and 8 , thickening to about $0.5 \mathrm{kilometers} \mathrm{beneath} \mathrm{station} 7$, correlates to the large area of mapped Quaternary glacial and alluvial deposits. The eastern half of the 10 ohm-meter unit thins rapidly near the edge of station 9 which was measured adjacent to rocks related to the Idaho Batholith. The western half of the $10 \mathrm{ohm}-$ meter unit thins more gradually as we approach station 5 ending adjacent to station 4. Mapped Quaternary deposits do occur directly adjacent to station 4 to the northeast and in a narrow north trending channel beneath station 5. The localized, thin near-surface $10 \mathrm{ohm}$-meter unit beneath station 3 correlates to a mapped fault. 
The 60 ohm-meter unit beneath stations 1 to 6 we have assigned to the Miocene Columbia River Basalt. Stations 1 to 4 were measured over mapped Columbia River Basalt. Station 5 was measured over a narrow north trending channel of mapped Quaternary alluvial deposits, but mapped Columbia River Basalt abuts each side of the narrow channel. The buried 200 ohm-meter unit in the upper 5 kilometers beneath stations 1 to 4 we interpret to be volcanic arc terrane because its moderate resistivity is a typical value (100-300 ohm-meters) for volcanic rocks and Triassic volcanic arc terrane outcrops directly northwest of station 1. The 1,000 ohm-meter unit beneath stations 1, 2, and with its eastern edge near station 3 (Figure 3a), we interpret to be an intrusion based both on its moderately high resistivity and, also, on its correlation to a north by northeasterly trending magnetically high intensity anomaly

(McCafferty, 1995; Zietz, et al., 1978) over stations 1 and 2. We have assigned the inferred intrusion to the Mesozoic because we were not able from our data alone to determine whether the intrusion belongs to the Triassic, Jurassic or Cretaceous and it appears to intrude rocks we interpret to belong to the Triassic.

The low-resistivity (10 and 30 ohm-meter) units underneath the interpreted arc units and inferred intrusion are consistent with resistivities expected for Paleozoic carbonaceous rocks. However, it is possible that the low-resistivity units are younger (Mesozoic) oceanic metasedimentary units, because of the location of the .704-.706 line and magnetite/ilmenite boundary that delineates the edge of the Pre-Cretaceous continent (Figure 3a). Regardless of age, these conductive rocks are of significance to mineral assessment, because carbonaceous rocks are an important intermediate repository of metallic minerals that become available for epithermal mobilization when heat sources are emplaced. The deep $10 \mathrm{ohm}$-meter unit is also consistent with resistivities expected for sedimentary rocks containing thermal fluids. Interpretation for a deep thermal source in this part of the profile is supported by evidence of hot springs near stations 3, 4, and 5 (McCafferty, 1995).

The eastern half of the profile crosses the continental margin that is defined approximately by the Sr87/Sr86, .704-.706 isopleth (Armstrong, et al., 1977) and traverses the entire Idaho batholith and western edge of the Challis volcanic field. Again, working our way down from the surface, of our interpreted crosssection (Figure 3b), this time beginning with the eastern half of the profile, we find extremely high-resistivity $(2,000-20,000$ ohm-meters) units which are consistent with resistivities expected for mapped Idaho batholith rocks just east of station 9, directly beneath stations 10 to 15 and on the edge of stations 17 and 18. This high-resistivity unit also extends west of station 9 at depth as far west as station 5 (Figure $3 a$ ), however, it is 
relatively thin here, (about 6.5 kilometers thick) thickening to about $30 \mathrm{kilometers} \mathrm{over} \mathrm{stations} 15$ to 18 . The extremely high resistivities of the plutonic rocks imply very little fracturing within the plutonic rocks, thus limited vertical permeability for mineralizing fluids. The near-surface $100 \mathrm{ohm}$-meter unit measured under stations 12 and 13 correlates to known hot springs (McCafferty, 1995) near station 12 and adjacent to station 13 . The mapped Precambrian rocks beneath station 16 appear to have resistivities above $1,000 \mathrm{ohm}$-meters which are too similar to the resistivities of the Idaho batholith rocks to delineate their boundary with them. The 1ithology of the $200 \mathrm{ohm}$-meter rocks occurring beneath the higher resistivity units of the Idaho batholith are unknown, but are probably basement metamorphic rocks that were part of the pre-cretaceous continental margin. These units were intruded by Cretaceous and Tertiary plutonic rocks.

The 60 ohm-meter unit directly beneath stations 17, 18, 19, and 20 we have assigned to the Tertiary Challis volcanics. Stations 19 and 20 were measured over mapped Challis volcanics and stations 17 and 18 were adjacent to the challis volcanics. The 1,000 ohm-meter unit beneath the challis volcanics we interpret to be a Tertiary intrusion based both on its moderately high resistivity and, also, on its correlation to a north by north-easterly trending magnetically high intensity anomaly (McCafferty, 1995; Zietz, et al., 1978) over stations 19 and 20. According to Bennett (1980), Tertiary intrusions were responsible for mineralization at the Yellow Pine mine (Figure 3b) and at Stibnite, while the challis volcanics represent ejecta above magma chambers that formed Tertiary plutons. Tertiary intrusions cause contact metamorphism which can result in mineral deposits (Stotelmeyer, 1989). The $200 \mathrm{ohm}$-meter unit beneath stations 17, 18 and 19 in the upper 2 kilometers we interpret to be extensive alteration of the Idaho batholith caused by the inferred intrusion east of station 18. The inferred intrusion was probably also the source of heat for contact metamorphism which resulted in mineralization at the Dewey mine and Sunnyside mine (Figure 3b).

The very conductive (10 ohm-meter) deep (10-30 kilometers) rocks beneath soundings 19 and 20 to the east of stibnite are consistent with resistivities expected for sedimentary rocks containing thermal fluids. Interpretation for a deep thermal source in this part of the profile is supported by evidence of hot springs near stations 19 and 20 (McCafferty, 1995). The 10 ohm-meter unit at a depth of 30 kilometers beneath the entire profile is interpreted to be subcrustal magma. 


\section{SUMMARY AND CONCLUSIONS}

The regional findings are quite significant for design of a detailed program to delineate mineral resources. The French Creek Roadless Area is north of the west end of the magnetotelluric profile in the area of soundings 5 to 9 (Figure 1). The coincidence of the .704-.706 line and evidence for deep thermal fluids (Figure 3) may make this area a prime candidate for mineral resource exploration. Many of the disseminated gold deposits in Nevada lie close to the .704-.706 line; the interpretation for this correlation has generally involved a complex interaction of subcrustal magmas and fluids. Such a sedimentary complex would provide a metallic-enriched host for hydrothermal systems generated by the batholithic intrusions. The tectonic setting makes the French Creek Roadless Area considerably more promising than the other three study areas near this magnetotelluric profile. 


\section{REFERENCES CITED}

Armstrong, R. L., Taubeneck, W. H., and Hales, P. O., 1977, Rb-Sr and $\mathrm{K}$-Ar geochronometry of Mesozoic granitic rocks and their Sr isotopic composition, Oregon, Washington, and Idaho: Geological Society of America Bulletin, v. 88, p. 397-411.

Bennett, E. H., 1980, Granitic rocks of Tertiary age in the Idaho batholith and their relation to mineralization: Economic Geology, v. 75, p. 278-288.

Bond, J. G., 1978, Geologic Map of Idaho: Idaho Department of Lands, Bureau of Mines and Geology. 1:500,000 scale.

Booker, J. R., 1991, Removal of static distortion from 2-D inversions of MT data [abs.]: American Geophysical Union Fall Meeting, Program and Abstracts, p. 129.

Brooks, H. C., 1979, Plate tectonics and the geologic history of the Blue Mountains: Oregon Geology, v. 41, no. 5, p. 71-80.

Gamble, T. D., Goubau, W. M. and Clarke, J., 1979, Magnetotellurics with a remote magnetic reference: Geophysics, v. 44, no. 1, p. 53-68.

Hamilton, W. B., 1978, Mesozoic tectonics of the Western United States: in Howell, D. G., and K. A. McDougall, eds., Mesozoic Paleogeography of the Western United States: Society of Economic Paleontologists and Mineralogists, Pacific Section, Pacific Coast Paleogeography Symposium, p. $33-70$.

Kaufman, A. A., and Keller, G. V., 1981, The Magnetotelluric Sounding Method: Elsevier, New York, 595 p.

Keller, G. V. and Frischknecht, F. C., 1966, Electrical methods in geophysical prospecting: Pergamon Press, New York, $517 \mathrm{p}$.

McCafferty, A. E., 1995, Assessing the presence of a buried meteor impact crater using geophysical data, south-central Idaho: MS thesis T-4651, Colorado School of Mines, Golden, Colorado, $122 \mathrm{p}$.

Nelson, P. H. and Anderson, L. A., 1992, Physical properties of ash flow tuff from Yucca Mountain, Nevada, Journal of Geophysical Research, v. 97, no. B5, p. 6823-6841. 
Smith, J. T., and Booker, J. R., 1988, Magnetotelluric inversion for minimum structure: Geophysics, v. 53, p. 1565-1576.

1991, Rapid inversion of two- and three-dimensional magnetotelluric data: Journal of Geophysical Research, v. 96, p. 3905-3922.

Sternberg, B. K., Washburne, J. C., and Pellerin, L., 1988, Correction for the static shift in magnetotellurics using transient electromagnetic soundings: Geophysics, v. 53, p. $1459-1468$.

Stotelmeyer, R. B., 1989, Idaho Land Assessment Program: administrative report, U.S. Bureau of Mines, Spokane.

Vozoff, K., 1991, The magnetotelluic method, in Electromagnetic methods in applied geophysics, vol. 2, part B, p. 641-711, ed. M.N. Nabighian: Society of Exploration Geophysicists, Tulsa, Oklahoma.

Zietz, I., Gilbert, F. P., and Kirby, J. R., Jr., 1978, Aeromagnetic map of Idaho: U.S. Geological Survey Geophysical Investigations Map GP 920. 


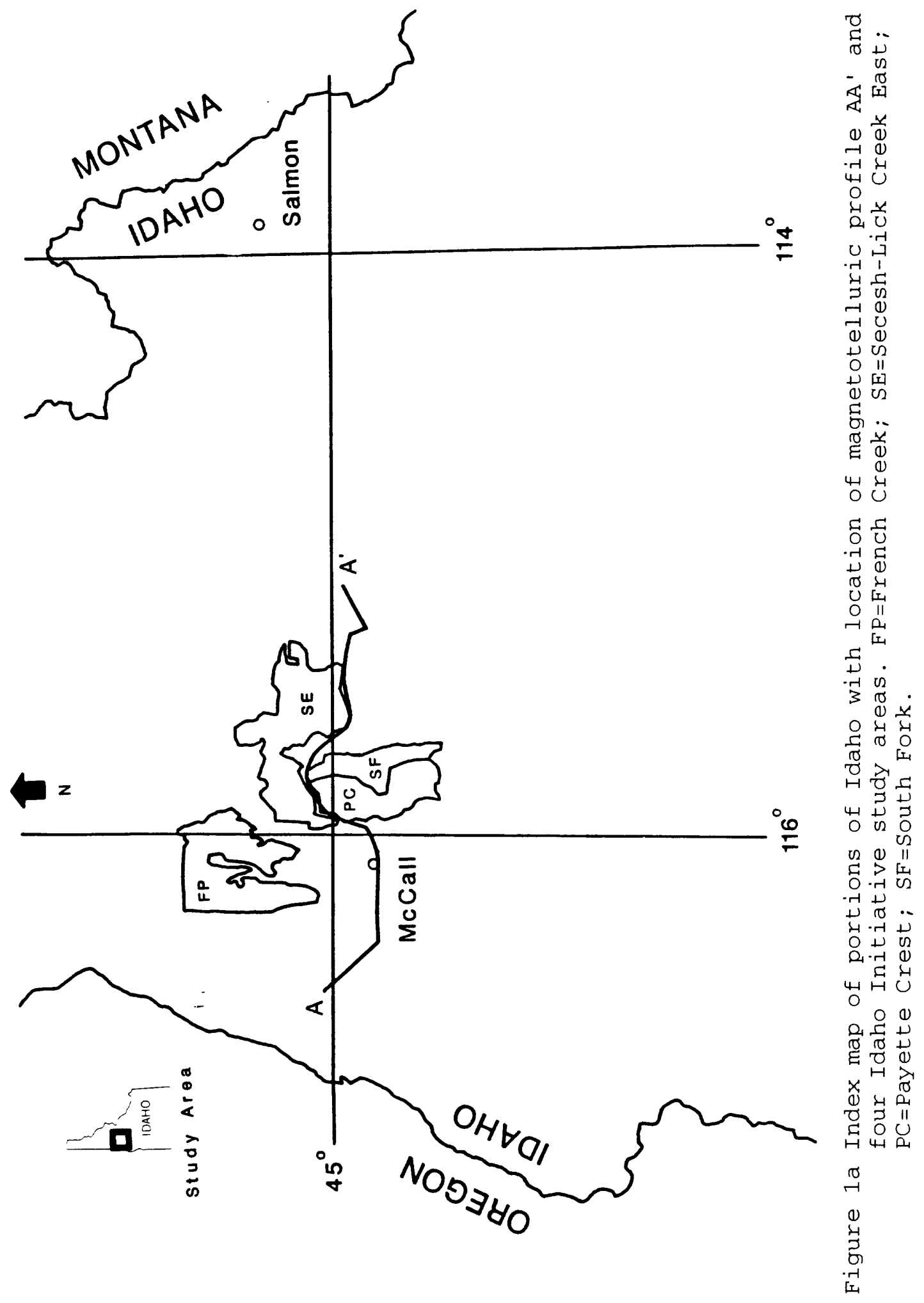









\section{SUMMARY OF MAP UNITS}

\section{SEDIMENTARY ROCK CONTINENTAL DEPOSITS}

\section{CENOZOIC UNITS}

Quaternary alluvium; may contain some glacial deposits and colluvium in uplands.

Qg Quaternary colluvium, fanglomerate and talus plus some glacial debris in upland valleys.

$\mathrm{CP}_{\mathrm{g}}$ Pleistocene outwash, fanglomerate, flood and terrace gravels.

$Q p_{c}$ Pleistocene upland valley deposits; commonly derived from alpine glaciation.

\section{MESOZOIC UNITS}

\section{DEEP MARINE-TO-TRANSITIONAL DEPOSITS}

$K_{v}$ Middle and Lower Triassic metabasalt and submarine volcaniclastic of western Idaho.

\section{PALEOZIOC UNITS}

Upper Permian submarine volcanic complex in the Snake Canyon of western Idaho.

PPC Lower Permian to Middle Pennsylvanian thrusted, marine detritus of central Idaho

Dc Devonian thrusted, deep-water siliceous argillite and quartzite of central Idaho.

DSc Devonian and Silurian thrusted, deep-water argillite beds of central Idaho

\section{IGNEOUS ROCK \\ EXTRUSIONS}

Extrusive rock compositions may be denoted by subscripts: "b" basaltic; as basalt or lava;

" $\mathrm{v"}$ volcanic; as mised types including volcaniclastic units.

\section{CENOZOIC UNITS}

Basalt

ind

trijl $l_{b}$ Miocene basalt flows, commonly porphyritic and exposed on lower slopes.

Mixed Volcanic Lithologies

$\mathrm{Te}_{4}$ Eocene mixed silicic and basaltic volcanic ejecta, flows and reworked debris.

\section{INTRUSIONS}

Intrusive rock composition may be denoted by a second subsript:

" $\mathrm{i}$ " intermediate; as granodiorite or diorite.

$\mathrm{Te}_{i}$ Eocene intrusions including large granitic plutons and dike swarms of central Idaho

Hi Cretaceous plutons; probably includes unmapped older na dyounger crystalline bodies.

ati:

Af Lower Cretaceous to Upper Jurassic intrusions in west-central Idaho

hil. Lower Mesozoic intrusions; localized near the Snake Canyon of western Idaho.

\section{METAMORPHIC ROCK}

:Ë: Precambrian, high-grade metamorphic rock
STRUCTURE

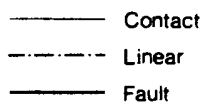
covered

Aـ Thrust fault (teeth on upper plate)

A covered or inferred

$\longrightarrow$ Syncline

\pm Anticline

ीि Overturned syncine

คी Overturned anticlıne

EXTRUSIVE

* Volcanic vent

Volcanic feeder - fissure

II Caidera

INTRUSIVE

Tertiary dike

Magnetotellurlc station

Thermal spring
Figure 1c Summary of map units.

from

Bond. J.G., 1978, Geologic map of Idaho: Idaho Department of Lands, Bureau of Mines and Geology 



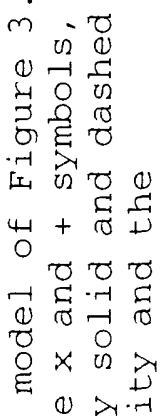

근?

ट

- 0 ठ

U 0 U

(ब) $>>1$

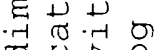

$1 \cdot-1 \cdot-1$

$\circ$ ర

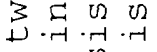

(1) (1) थ 0
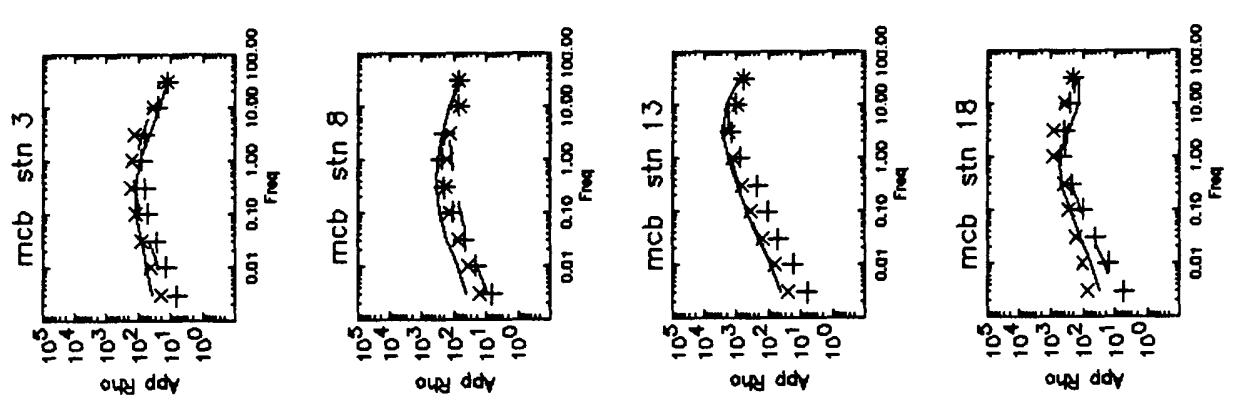

मै मु मे

म $\sigma \sum_{0}$

$0 \perp$

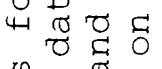

(1) त्र

.

$>-\pi \sigma^{-1}$

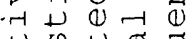

$\perp$ थ

- $\rightarrow$ o 0 .

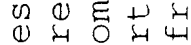
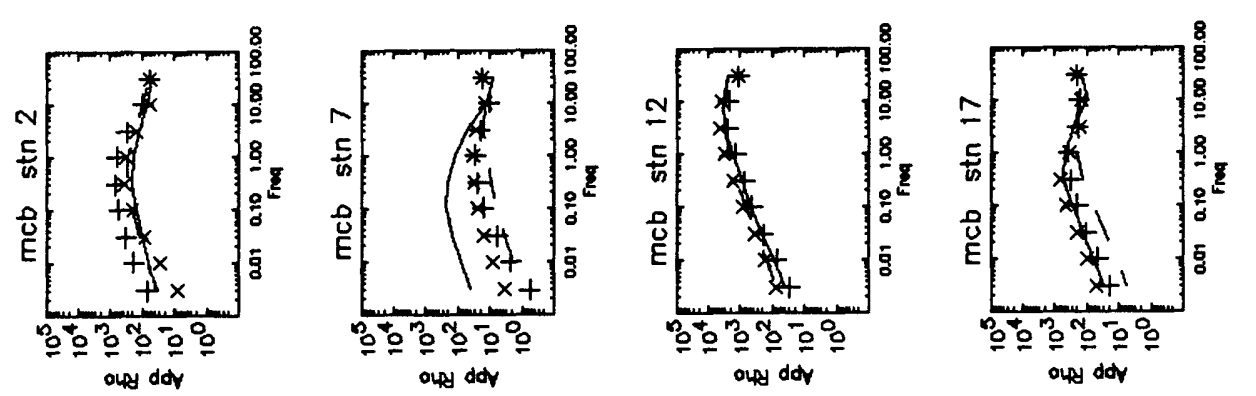

$\nabla \sum>0$

ช

ป ठ

है $\approx 0$.

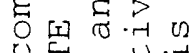

$\nabla \sigma>0$

¿ 01

\& $>0$

Tु 0.7 .

$>0$ - 0

40 \& 20
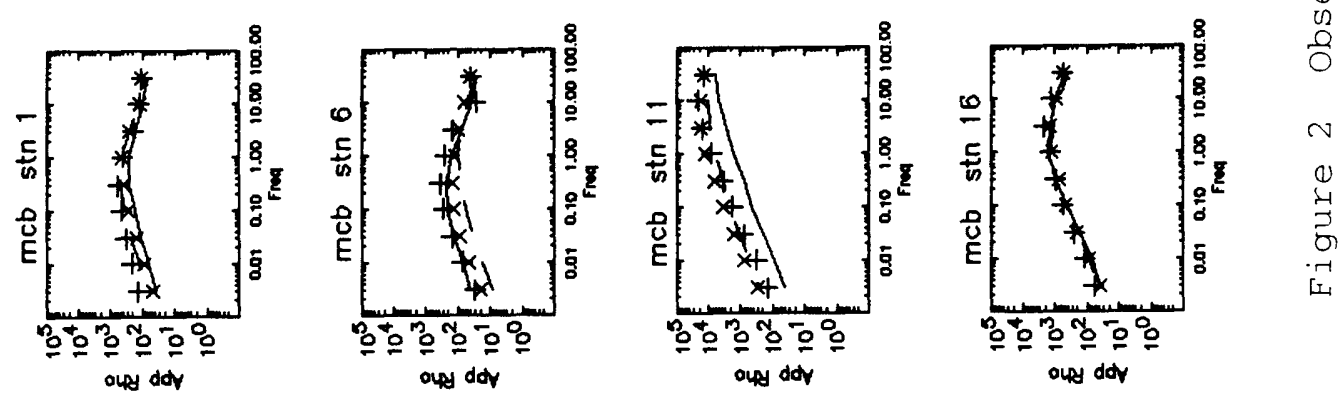


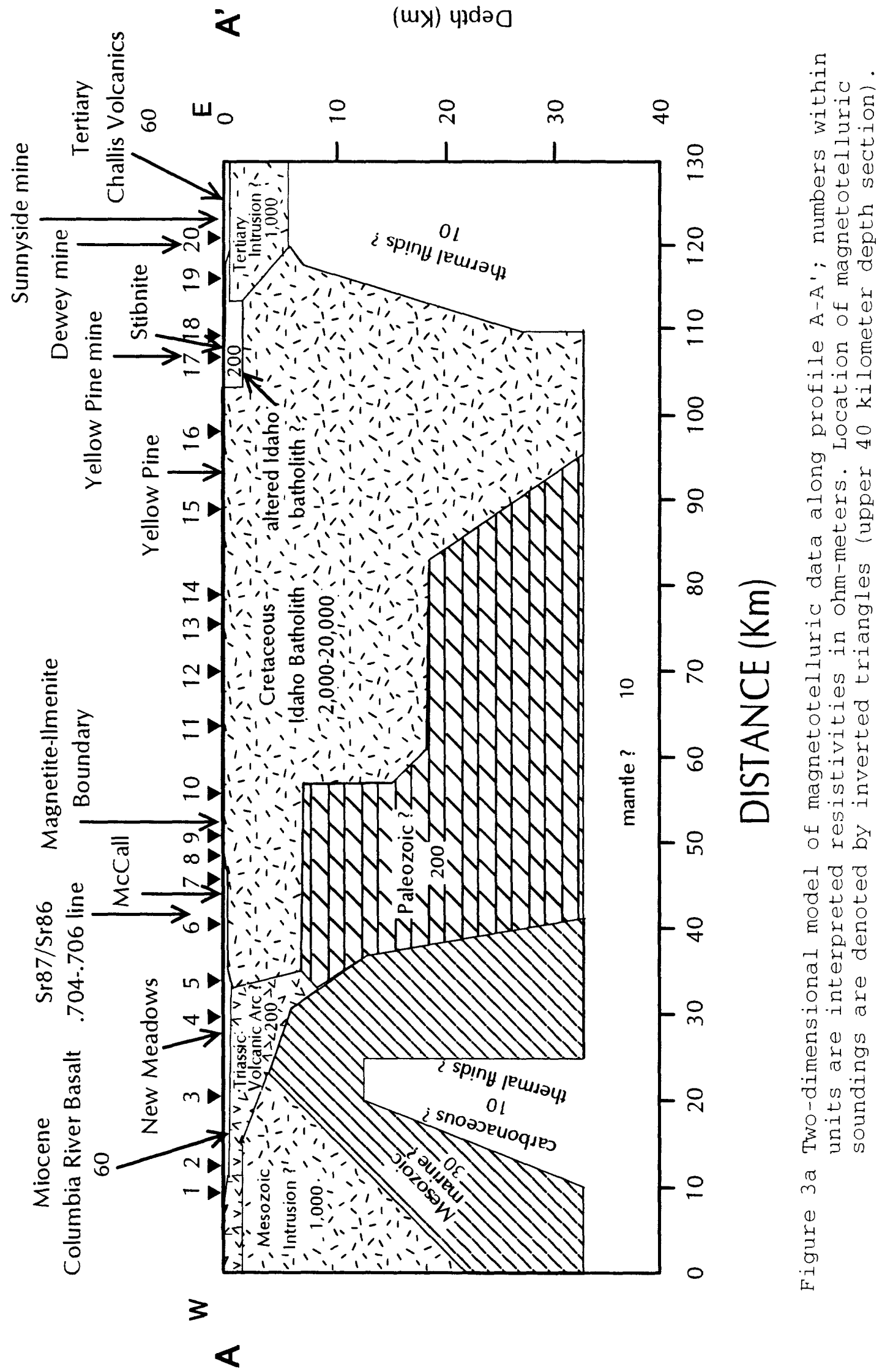






